\title{
Cadaver as an experimental model to study the effect of muscle advancement on the waistline ${ }^{1}$
}

\author{
Fábio Xerfan Nahas ${ }^{2}$ \\ Lydia Masako Ferreira ${ }^{3}$
}

Nahas FX, Ferreira LM. Cadaver as an experimental model to study the effect of muscle advancement on the waistline. Acta Cir Bras [serial online] 2004 Vol 19 Special Edition. Available on URL: http://www.scielo.br/acb.

\begin{abstract}
The use of cadaver as an experimental model to evaluate the waistline after correction of rectus diastasis and the advancement of the external oblique muscles in cadavers were described on this article. Two parameters were used: the measurement of the abdominal circumference and the overlap of the two skin flaps formed by a xypho-pubic incision. With a previously marked area of undermining of the aponeurotic layer, measurements of the overlapped flaps were made in the following stages of dissection: 1) with the myo-aponeurotic layer intact; 2) after the correction of rectus diastasis; and 3) after the advancement of the external oblique muscle. The experimental model described showed to be feasible to demonstrate the effects of the correction of rectus diastasis and of the advancement of external oblique muscles on the waistline.
\end{abstract}

KEY WORDS - Abdominoplasty. External oblique muscle. Abdominal wall.

\section{Introduction}

Improvement of the waistline is one of the goals of abdominoplasty. However, its shape depends on several factors such as fat deposit, individual abdominal contour and the degree of muscular tension.

Several techniques of muscular reinforcement to achieve a more harmonious contour of the anterior abdominal wall have been described ${ }^{1,2,3}$. These techniques are basically focused on the tension of the abdominal wall and, as a consequence, some improvement is possible at the waistline.

\footnotetext{
${ }^{1}$ Study developed in the Plastic Surgery Division, Federal University of São Paulo - São Paulo Medical School

${ }^{2} \mathrm{PhD}$, Interim Professor of Plastic Surgery of Federal University of São Paulo - UNIFESP/EPM

MD, PhD, Titular and Head of the Plastic Surgery Division, Federal University of Sao Paulo - Sao Paulo Medical School.
} 
Appiani ${ }^{4}$ described a technique that improves the abdominal contour and definition of the waistline by rotating the external oblique muscle. Only one study focused on the consequences of this technique on the waist circumference ${ }^{5}$.

\section{Proposition}

The purpose of this study is to report and bring to light the use of cadaver as an experimental model to evaluate the waistline after correction of rectus diastasis and advancement of the external oblique muscles in cadavers.

\section{Method description}

Fresh cadavers with intact abdominal were studied. The procedure was performed at $22^{\circ} \mathrm{C}$.

With the cadaver in supine position, the abdominal circumference was measured at the level of the umbilicus. This level was marked with Methylene blue from the umbilicus towards the flanks of the cadaver (FIGURE 1). The mark served as a reference for the next measurements and permitted a more faithful positioning of the ruler around the abdomen.

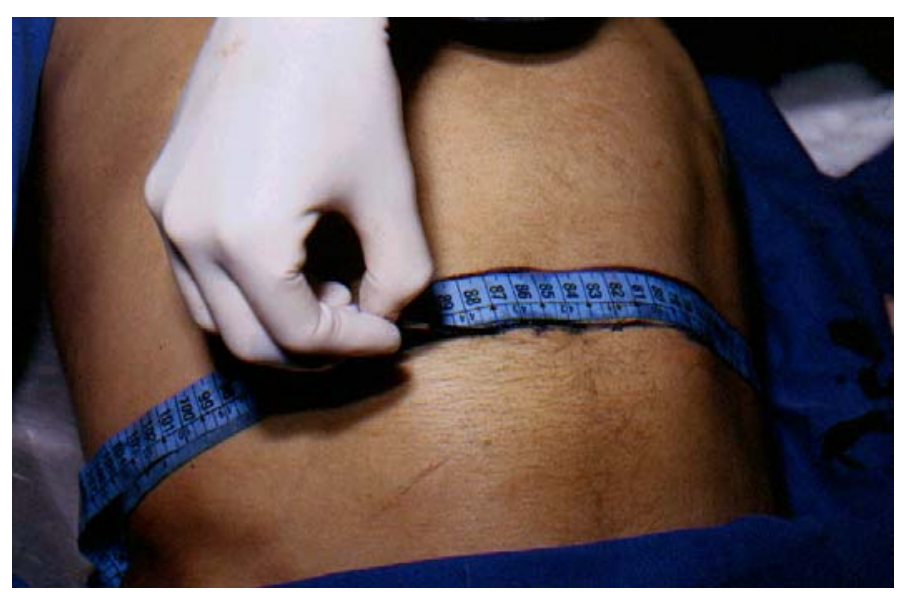

FIGURE 1 - Shows the measurement of the abdominal circumference. The area where the ruler was positioned was marked with methylene blue.

An incision from the xyphoid process to the pubis was performed, exposing the linea alba. The abdominal skin flap, on both sides, was separated from the aponeurosis and muscles of the anterior abdomen, in the same extension as during an abdominoplasty. The superior limit of dissection was at the level of the lower ribs and $2 \mathrm{~cm}$ below the xyphoid appendix, inferiorly the undermining extended to $1 \mathrm{~cm}$ above the pubis and laterally, to the level of the anterior axillary line. (FIGURE 2). 


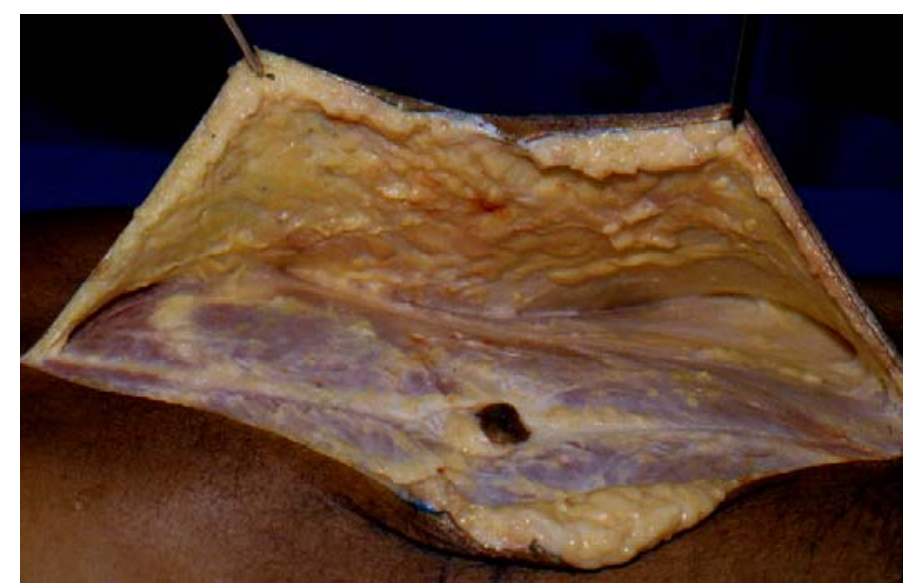

FIGURE 2 - The exposure of the aponeurotic layer, reaching laterally the anterior axillary line.

\section{Dissection - Initial Stage}

The two abdominal skin edges, at the previously marked level of the umbilicus, were overlapped with the right flap over the left flap, without any tension. At this moment the aponeurosis was intact. The width of the overlapped skin was measured (FIGURES 3 e 4). These values were obtained at the initial stage of dissection.

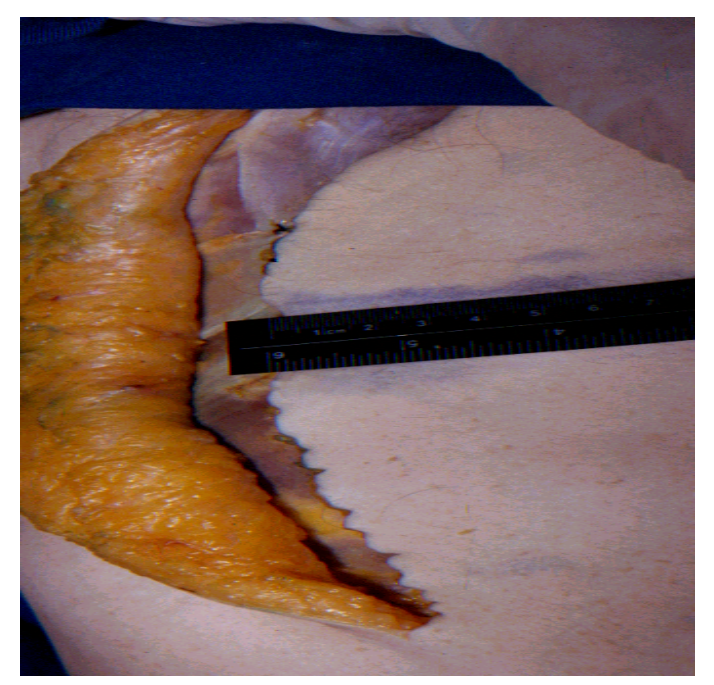

FIGURE 3 - The left abdominal skin flap is placed toward the opposite side under no tension. A ruler is placed at the edge of the flap, on the previously marked area. 


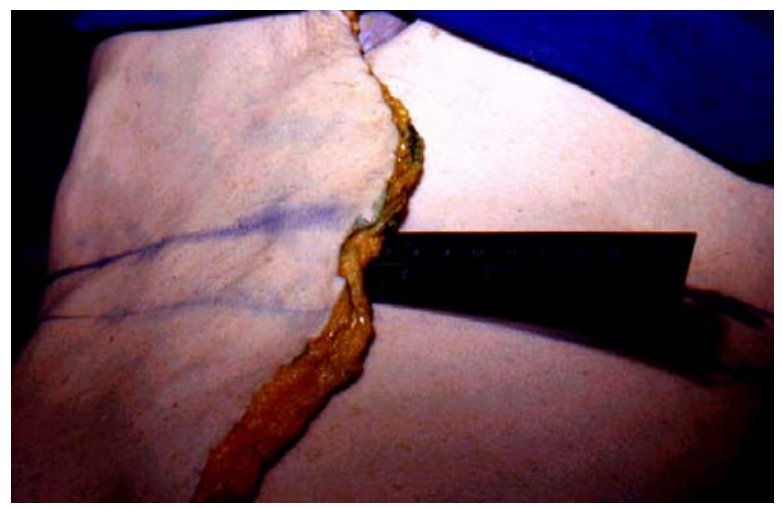

FIGURE 4 - The right abdominal flap is placed over the left flap, under no tension. The flap overlap is then measured.

\section{Dissection - Stage 1}

Approximation of the rectus muscles was performed at this stage. The anterior rectus sheath was incised along the medial edge of the rectus abdominis muscle from the costal margins to $1 \mathrm{~cm}$ above the pubis. The rectus muscle was separated from its posterior rectus sheath and from the transversalis fascia, below the arcuate line. A plication of the posterior rectus sheath was performed invaginating the linea alba. The recti muscles, attached to the anterior sheath, were sutured to each other and anchored to the midline (FIGURE 5). This was called stage 1 of dissection and the width of the overlapped flaps was again measured as described previously.

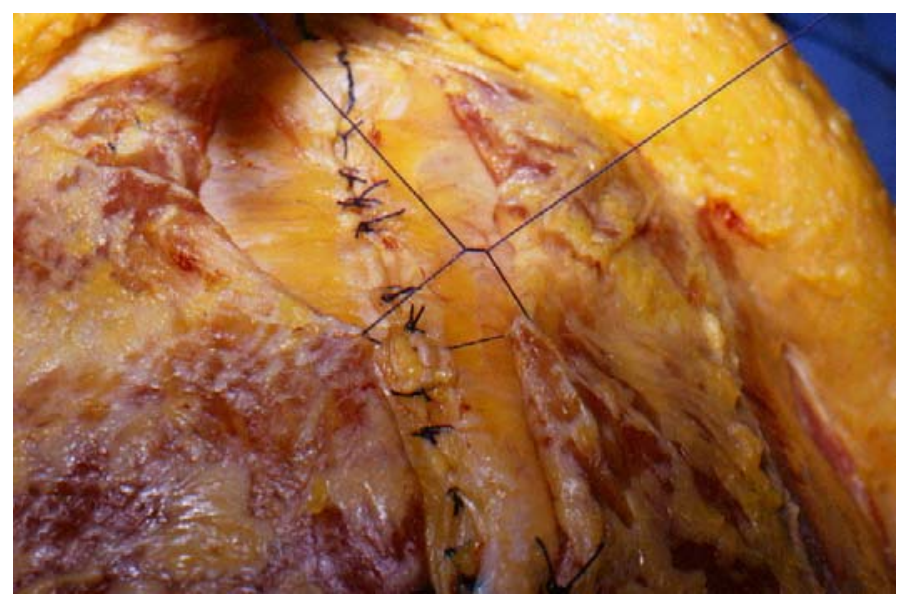

FIGURE 5 - Rectus diastasis is corrected by the advancement of the rectus muscles (Stage 1). 


\section{Dissection - Stage 2}

The external oblique aponeurosis was released along the semilunaris line from the costal margins to its natural arch inferiorly, parallel to the reflected inguinal ligament. The external oblique muscle was undermined laterally towards the anterior axillary line where its neurovascular pedicle penetrates the muscle. This muscle was rotated and advanced to the midline and sutured to the contralateral one (FIGURE 6). These muscles were advanced avoiding exaggerated traction. The width of the overlapped skin flap was again measured in the so called stage 2 of dissection.

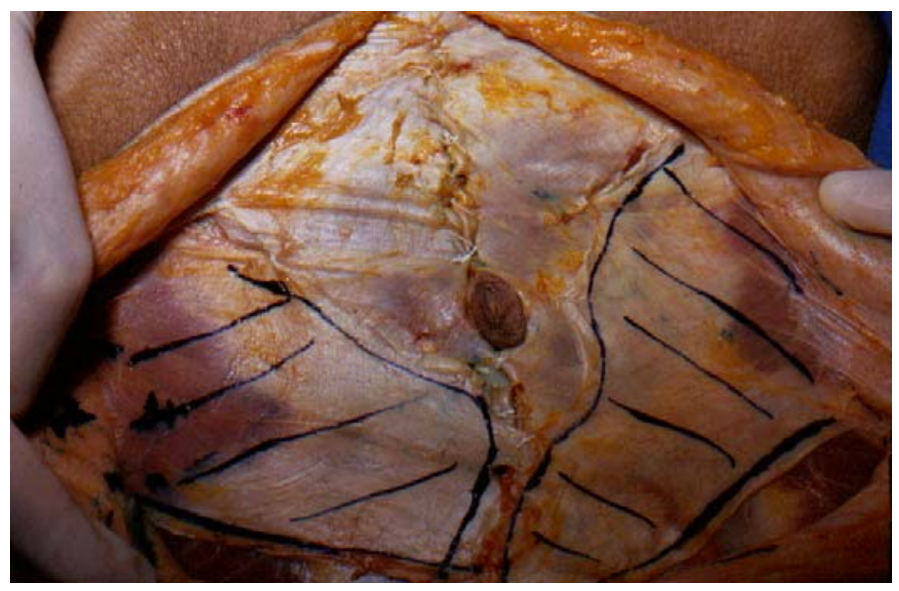

FIGURE 6 - The external oblique muscles were advanced toward the midline. Muscles were marked with methilene blue to allow a better visualization (Stage 2).

The skin edges were brought together and carefully sutured, avoiding invagination of the skin. The abdominal circumference was again measured on the marked skin, at the level of the umbilicus (FIGURE 7).

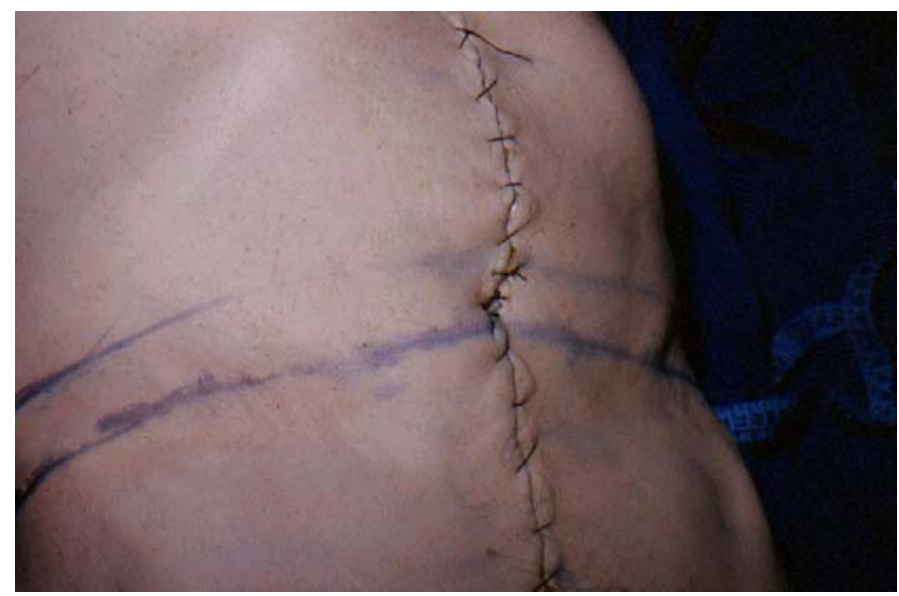

FIGURE 7 - Final aspect after skin suture is seen. At this moment the new waist circumference was measured. 


\section{Perspectives}

The experimental model described showed to be feasible to demonstrate the effects of the correction of rectus diastasis and the advancement of the external oblique muscles on the waistline. This model may be used to evaluate different techniques to correct myo-aponeurotic deformities such as the plication of the anterior rectus sheath, plication of the external oblique aponeurosis and abdominal liposuction.

\section{References}

1.Nahas FX - Resistência Músculo-Aponeurótica Da Parede Abdominal À Tração Medial Após Secção E Descolamento Aponeurótico Seletivo. [Tese]. Faculdade de Medicina da Universidade de São Paulo; 1997.

2.Nahas FX, Ishida J, Gemperli R, Ferreira MC - Abdominal wall closure after selective aponeurotic incision and undermining. Ann Plast Surg. 1998;41(6):606.

3.Pina DP - Aesthetic abdominal deformities: a personal approach to the posterior rectus sheath and rectus muscles. Plast Reconstr Surg. 1985;75:660.

4.Appiani E - Muscular plastic for aesthetic conformation of abdominal girdle. Ann Plast Surg. 1984;13(2):97.

5.Nahas FX - Advancement of the External Oblique Muscle Flap to Improve Waistline - A Study in Cadavers. Plast Reconstr Surg. 2001;108(2):550-5.

Nahas FX, Ferreira LM. Cadáver como modelo experimental para avaliar o efeito do avanço muscular na cintura. Acta Cir Bras [serial online] 2004 Vol 19 Edição Especial. Disponível em URL: http://www.scielo.br/acb.

RESUMO - O uso de cadáver como modelo experimental para avaliar a cintura após a correção da diástase de retos e o avanço dos músculos oblíquo externos é descrito neste estudo. Dois parâmetros foram utilizados: a medida da circunferência abdominal e a sobreposição de dois retalhos dermogordurosos formados por uma incisão xifo-púbica. Após a definição da área de descolamento supra-aponeurótico, a medida da sobreposição dos retalhos foi realizada nas seguintes fases de dissecção: 1) com o plano mio-aponeurótico íntegro; 2) após a correção da diástase de retos; e 3) após o avanço dos músculos oblíquos externos. O modelo experimental descrito mostrou-se viável para demonstrar os efeitos da correção da diástase de retos e no avanço dos músculos oblíquo externos na cintura.

DESCRITORES - Abdominoplastia. Músculo oblíquo externo. Parede abdominal.

Correspondence:

Fabio Xerfan Nahas

UNIFESP-EPM, Plastic Surgery Division, Surgery Division

Rua Napoleão de Barros, $715,4^{\circ}$ andar

04024-900 São Paulo - SP

Tel: (11)557604118 FAX: (11) 55716579

sandra.dcir@epm.br

fabionahas@uol.com.br 